\title{
Vitex trifolia: AN ETHNOBOTANICAL AND PHARMACOLOGICAL REVIEW
}

\author{
SUCHITRA M, BINOY VARGHESE CHERIYAN*
}

Department of Pharmaceutical Chemistry and Analysis, School of Pharmaceutical Sciences, Vels Institute of Science, Technology and Advanced Studies, Pallavaram, Chennai, Tamil Nadu, India. Email: lallybinoy@gmail.com

Received: 10 October 2018, Revised and Accepted: 11 December 2018

ABSTRACT

Objective: The perspective of this review is the list of activities carried out or studied along with description, habitat macro-microscopy, phytoconstituents, medicinal uses, clinical studies, and toxicology on the plant Vitex trifolia.

Methods: A large number of the species of the Genus Vitex are widely employed in Indian traditional systems of medicine. A total of 270 plant species of genus Vitex have been identified worldwide. V. trifolia is used in Ayurveda and Unani. These species are rich source of secondary metabolites such as polyphenolic compounds, terpenoids, phytosterols, protein and amino acids, tannins, and saponins.

Results: The results of various studies $V$. trifolia possess larvicidal, analgesic, anti-inflammatory, antimicrobial, antioxidant, hepatoprotective, antihistaminic, and antiasthmatic properties.

Conclusion: The review on $V$. trifolia explains that there is a need for detailed study on its clinical relevance and safety of plant extracts.

Keywords: Larvicidal, Analgesic, Anti-inflammatory, Antimicrobial, Antioxidant, Hepatoprotective, Antihistamine and antiasthmatic, Wound healing, Vitex trifolia.

(C) 2018 The Authors. Published by Innovare Academic Sciences Pvt Ltd. This is an open access article under the CC BY license (http://creativecommons. org/licenses/by/4. 0/) DOI: http://dx.doi.org/10.22159/ajpcr.2018.v11s4.31689

\section{INTRODUCTION}

Plants used in traditional system of medicine have the advantage little or no side effect. Most of the species of the genus Vitex are widely used in traditional Indian systems of medicine. Around 270 plant species of genus Vitex have been reported worldwide [1,2]. Vitex trifolia belongs to the family Lamiaceae. V. trifolia is an aromatic coastal deciduous shrub or small plant growing from 1-4 m tall (Fig. 1)

\section{MACROSCOPIC EVALUATION}

The green leaves of $V$. trifolia have resinous glands tomentose beneath and 7-12 pairs of lateral nerves, terminal, and supraaxillary, $5-26 \mathrm{~cm}$ long panicles [3]. Three-foliolate leaflets are elliptic or oblong-obovate, slender, canaliculate, $0.5-3.5 \mathrm{~cm}$ long, and grey-appressed petioles. Usually obtuse or acute to cuneate at base, entire along margins, acuminate at apex lengthy leaflet, middle leaflets $2.5-6.5 \times 1-3.5 \mathrm{~cm}$, petiolules $0.5 \mathrm{~cm}$ long, lateral leaflets are $2.5-4.5 \times 1-1.5 \mathrm{~cm}$ the terminal leaflet sessile, $5-6.3$ by $2.5-3.8 \mathrm{~cm}$ the lateral smaller, sessile, all glabrous above, very densely white-tomentose beneath, base tapering; common petioles $1.3-1.6 \mathrm{~cm}$ long [4]. The stems are usually procumbent often rooting at the nodes and annulate nodes and 2.5$5 \mathrm{~cm}$ long internodes forming mats several meters in diameter and with soft hair called tomentose, fragrant flowers with pedicels of $0.5-1 \mathrm{~cm}$ long. Calyx campanulate the flowers are born in panicles with purple to violet two-lipped corollas and the fruits $6 \mathrm{~mm}$ in diameter bearing four small black seeds [5]

\section{MICROSCOPIC EVALUATION}

The leaflet has smooth adaxial surface $140 \mu \mathrm{m}$ thick along the ridged part of the leaflet and $120 \mu \mathrm{m}$ thick in between the ridges. Thick and prominent adaxial epidermis with rectangular cell and fairly thick walled subepidermal layer with $10 \mu \mathrm{m}$ thin cuticle. The hypodermal layer is $15 \mu \mathrm{m}$ thick. The midrib is thick. The epidermal layer is a narrow with small cells. The ground tissue of the midrib consists of circular thin-walled compact parenchyma cells [4]. The vascular system of the midrib has vascular strand consists of several parallel rows of xylem which are about six cells angular and thick walled with narrow parenchymatous space in between the xylem rows. The adaxial is circular and collateral the abaxial epidermis is narrow with dense nonglandular trichomes. The mesophyll consists of four layers cylindrical cells. The height of these palisade and spongy parenchyma cells reduced gradually toward the lower part.

\section{TAXONOMICAL CLASSIFICATION [6]}

Kingdom: Plantae, Class: Eudicots, Order: Lamiales, Family: Lamiaceae, Genus: Vitex, Species: Trifolia.

\section{Vernacular names}

- Sanskrit: Jalanirgundi,

- Hindi: Nichinda,

- Manipuri: Urikshibi,

- Bengali: Paniki-shumbala,

- Kannada: Nira-lakki-gida,

- Malayalam: Lagondi, Nirnoschi,

- Tamil: Nirnochchi, Shirunoch-chi,

- Telugu: Niruvavili, Shiruvavili.

\section{Phytochemical constituents}

The plant contains polyphenolic compounds, flavonoids, proteins, tannins, phytosterols, and saponins. Fruits of $V$. trifolia consist [7-9] of essential oil, Vitex trifolia A-G, monoterpenes along with diterpenes, dihydrosolidagenone, beta-sitosterol-3-0-glucoside, terpineol, alpha-pinene, 3,6,7-trimethylquercetagetin [10], hexanic, and dichloromethanic were extracted from stem [11]. The methyl- $p$-hydroxy benzoate was reported [12]. Six flavonoids have been isolated [13]. 15 compounds were isolated from $V$. trifolia. Leaves and bark contain an essential oil, flavones, artemetin and 7-dimethyl artemetin [14], friedelin, and some non-flavonoids and alkaloids. Caryophyllene is the major sesquiterpene. Vitricin, a new alkaloid, has been isolated from the plant [15] V. trifolia contains palmitic acid, ethyl-p-hydroxybenzoate, 


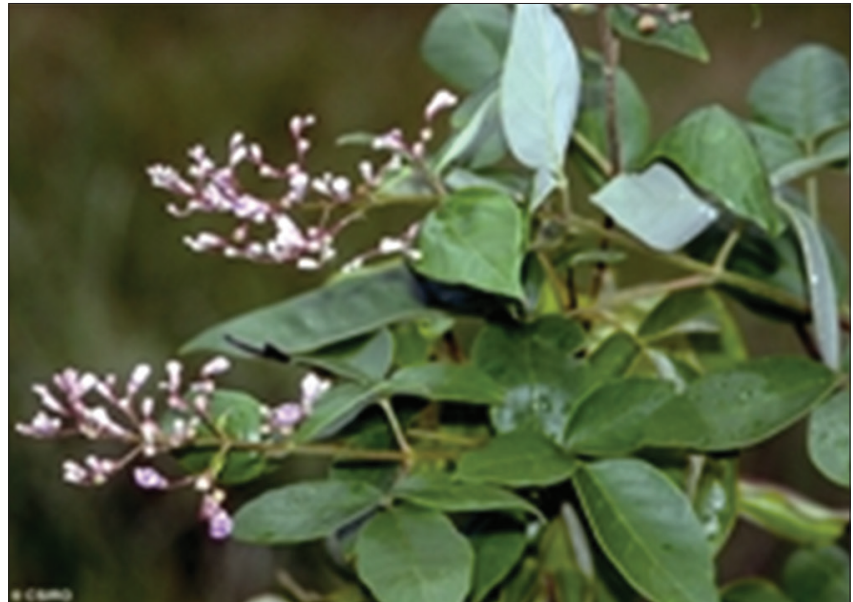

Fig. 1: Vitex trifolia

3,4-dihydroxybenzoic acid, 4-hydroxy-3-methoxybenzoic acid, caffeic acid, hydroxyl ethyl cinnamate, luteolin, quercetin, apigenin, casticin, and 3,6,7-trimethylquercetagetin. Phytochemical investigation of the ethyl acetate fraction afforded stigmasterol [16], caffeic acid [17], 7-O-glucopyranoside [18], 3,6,4'-trimethoxy quercetin 7-O-glucopyuranoside [19], and quercetin 7-O-neohespridoside [20].

\section{Traditional uses}

It is used as anti-inflammatory in Chinese folk medicine in the treatment of headaches, colds, migraine, eye pain [21], rheumatic pains, and cancer [22]. The leaves possess insecticidal, antibacterial activity [23], eczema, ringworm, liver disorders, spleen enlargement, rheumatic pain, gout, abscess, antiseptic, beriberi, diuretic, febrifuge, treating sprains, contusions, and swollen testicles $[24,25]$ and fruits an acid alkaloid and coloring matter are used in the treatment of amenorrhea, common cold, headache, watery eyes, and mastitis, to control population, nervine, cephalic, and emmenagogue which stimulate blood flow in the pelvic area and uterus. V. trifolia is known as sambhalu in Unani medicine in the treatment of decreasing libido. The inner bark is used for dysentery, expectorant, lowering blood pressure and treating common cold, prosopalgia, chronic tracheitis, sinusitis, periodontitis, and rheumatism and used in the treatment of pulmonary tuberculosis. The roots are used as antihelmintic, insecticidal, and diuretic.

\section{In vitro and in vivo studies}

\section{The larvicidal activity}

A comparative study of the extracts of Vitex species against larvae of Culex quinquefasciatus was performed. The fatty acid methyl ester extract of V. trifolia showed the highest larvicidal activity among these species and this activity can be attributed to the highest percentage of linolenic acid present in V. trifolia [20].

\section{Antinociceptive/anti-inflammatory}

The leaf extract of $V$. trifolia was explored for its role on nociception and found that it was effective in ameliorating pain. This study demonstrated the antinociceptive activity of $V$. trifolia and potentiated its antinociceptive effect with the standard analgesic agents. A dosedependent anti-inflammatory activity on acute model of inflammation was also reported [26].

Aqueous extract of leaves $V$. trifolia was tested on acute and chronic models of inflammation such as carrageenan-induced paw edema, granuloma pouch, and formaldehyde-induced arthritic models. Results showed significant inhibition of paw edema formation and also significant inhibition of exudates formation [27].

The antinociceptive potential of $V$. trifolia was studied using standard models of nociception such as acetic acid-induced writhing method and tail immersion test. In acetic acid-induced writhing method, a significant reduction in the number of writhes was clearly observed. In tail immersion method, the latent period to withdraw the tail was also recorded. Rats treated with the highest dose (400 mg) levels showed significant antinociceptive activity concluding that $V$. trifolia Linn. is effective ameliorating both central and peripheral nociception [28].

\section{Hepatoprotective/flowers}

The hepatoprotective effect of the ethanolic extracts of the flowers of $V$. trifolia was studied on rodent models and carbon tetrachlorideinduced hepatic injury model was employed. The hepatoprotective effect was comparable to standard drug, silymarin [29]. The serum was subjected to biochemical tests and found that a greater reduction in the liver enzymes such as serum glutamic-oxaloacetic transaminase, serum glutamic pyruvic transaminase, alkaline phosphatase, gamma-glutamyl transpeptidase, and total bilirubin; there was also an elevation in total protein level in rodents treated with ethanolic and aqueous extracts of $V$. trifolia. A significant rise in liver enzymes was reported in nontreated group indicating hepatic damage. The hepatoprotective effect of V. trifolia is also supported by histopathological finding normal hepatic architecture with few fatty lobules concluding that $V$. trifolia offered significant protection against $\mathrm{CCl}_{4}$-induced hepatocellular injury.

\section{Anticancer/antifungal}

Hexane and dichloromethane extracts of $V$. trifolia from aerial parts were reported to possess cytotoxic against various cell lines [10]. The hexanic extract of $V$. trifolia obtained from the leaves showed significant inhibition of the fungal plant pathogen Fusarium species. Another study [30] evaluated the cytotoxic effect of methanol and petroleum ether extracts against MCF-7 and Vero cell lines. Results of the study demonstrated strong cytotoxic against MCF-7 cell lines and weak activity against the Vero cell line, suggesting $V$. trifolia as promising chemotherapeutic agent in the treatment of breast cancer.

\section{Antiasthmatic}

The extracts of the leaves of $V$. trifolia were subjected to chromatography lead to isolation of three compounds, namely Viteosin-A, Vitexicarpin, and Vitetrifolin-E. Vitexicarpin was effective in controlling asthma through stabilization of mast cells membrane and non-competitive antagonism to histamine [31].

\section{Wound healing}

The ethanol leaf extracts of $V$. trifolia and Vitex altissima were tested for its potential wound healing activity. The study showed both extracts possessed significant wound healing activity. V. trifolia showed maximum healing activity by exhibiting enhanced wound contraction and reduced the period of epithelization as compared to V. altissima [32].

\section{Antibacterial}

The potential antibacterial activity of the extracts of Morindaci trifolia, V. trifolia (leaf), and Chromolaena odorata was assessed and the results were comparable for its antibacterial activity [33].

\section{Antitubercular diterpenoids/leaves [7]}

The alcoholic and petroleum ether extracts of $V$. trifolia leaves exhibited moderate inhibiting activity against Mycobacterium tuberculosis [34,35].

\section{CONCLUSION}

The plant $V$. trifolia is an aromatic coastal deciduous shrub grown India, Bangladesh, and Sri Lanka which is used as a traditional folk medicine for various ailments had been evaluated for in vitro antimicrobial, antioxidant, in vivo hepatoprotective, antinociceptive, antiasthmatic, antitubercular, and analgesic activity. The phytochemical constituent of the methanolic and ethanolic extracts of the aerial parts of the plant was evaluated and reported. Further, a detailed study on $V$. trifolia is necessary for the development of novel drugs in the 
arena antiandrogenic, antiarthritic, antidiabetic, antihypertensive, neuropathic, antiulcer, antipsychotic, and anticoronary activity to be done.

\section{ACKNOWLEDGMENT}

The authors are thankful to the School of Pharmaceutical Sciences, Vels Institute of Science, Technology and Advanced Studies, and its management for providing research facilities and encouragement.

\section{REFERENCES}

1. Kumar S, Saini M, Kumar V, Prakash O, Arya R, Rana M, et al. Traditional medicinal plants curing diabetes a promise for today and tomorrow. Asian J Tradit Med 2012;7:3173-84.

2. Kumar MA, Niranjan U, Rao M, Padhi MM, Babu R. A review of the important chemical constituents and medicinal uses of Vitex genus. Asian J Tradit Med 2011;6:54-60.

3. Jose BE, Jebaseelan S, Meera R. Phytochemical investigation and anticancer activity of Vitex trifolia. J Pharm Sci Res 2017;9:1056-62.

4. Thenmozhi S, Sundaram RS, Kumar JP, Bihari CG. Pharmacognostical and phytochemical investigation on leaves of Vitex trifolia Linn. J Pharm Res 2011;4:1259-62.

5. Van der Valk JM, Christiene L, Mark N. Macroscopic authentication of Chinese materia medica (CMM): A UK market study of seeds and fruits. J Herb Med 2017;8:40-51.

6. Meena A, Singh U, Yadav A, Singh B, Rao M. Pharmacological and phytochemical evidences for the extracts from plants of the genus Vitex-a review. Int J Pharm Clin Res 2010;2:1-9.

7. Cousins MM, Briggs J, Chuck G, Whitwell T, Whetstone J. Beach Vitex (Vitex rotundifolia) an invasive coastal species. Weed Sci Soc Am 1991;6:101-3.

8. Zeng X, Fang Z, Wu Y, Zhang H. Chemical constituents of the fruits of Vitex trifolia L. Zhongguo Zhong Yao Za Zhi 1996;21:167-8, 191.

9. Ono M, Sawamura H, Ito Y, Mizuki K, Nohara T. Diterpenoids from the fruits of Vitex trifolia. Phytochemistry 2000;55:873-7.

10. Hernández MM, Heraso C, Villarreal ML, Vargas-Arispuro I, Aranda E. Biological activities of crude plant extracts from Vitex trifolia L. (Verbenaceae). J Ethnopharmacol 1999;67:37-44.

11. Kannathasan K, Senthilkumar A, Venkatesalu V. Mosquito larvicidal activity of methyl-p-hydroxybenzoate isolated from the leaves of Vitex trifolia Linn. Acta Trop 2011;120:115-8.

12. Li WX, Cui CB, Cai B, Wang HY, Yao XS. Flavonoids from Vitex trifolia L. Inhibit cell cycle progression at $\mathrm{G} 2 / \mathrm{M}$ phase and induce apoptosis in mammalian cancer cells. J Asian Nat Prod Res 2005;7:615-26.

13. Arifin B, Nasution R, Saidi N, Marianne, Aprilia S. Vitex trifolia plant control of mice environmentally friendly. Int J Chem Tech Res 2014;6:4595-600.

14. Chan EW. Medicinal plants of sandy shores a short review on Vtrifolia L. and Iomoea pes caprae. Indian J Nat Prod Resour 2016;7:107-15.

15. Roqaiya M, Begum W, Majeedi SF. A review on unani traditional uses of sambhalu in females as well as phytochemical and pharmacological properties. Int J Pharm Sci Res 2017;7:31-41.
16. Mustariche R, Windhu WY, Ryan W. Anti-inflammation tablet of legundi (Vitex triolia) ethanol extract with variation of sodium starch glycolate. Int J Res Ayurveda Pharm 2016;7:114-7.

17. Ahmad FB, Holdsworth DK. Traditional medicinal plants of Sabah state Malaysia the rungus people of Kudat. Int J Pharmacogn 1995;33:262-4.

18. Bajpai A, Ojha JK, Sant HR. Medicobotany of the Varanisi district Uttar Pradesh. Int J Pharmacogn 1995;33:172-6.

19. Aranda E, Hernandez MM, Heraso C, Villarreal ML, Arispuro IV. Biological activities of crude plant extracts from Vitex trifolia L. J Ethnopharmacol 1999;67:37-44.

20. Kannathasan K, Senthilkumar A, Chandrasekaran M, Venkatesalu V. Differential larvicidal efficacy of four species of Vitex against Culex quinquefasciatus larvae. Parasitol Res 2007;101:1721-3.

21. Yasuyuki IT, Noharab T. Four new halimane-type diterpenes, vitetrifolins D-G, from the fruit of Vitex trifolia. Chem Pharm Bull 2001;49:1220-2.

22. Apichart S, Kittipong W, Joseph J. Variation of essential oil constituents in Vitex trifolia species. Flavour Fragr J 1991;6:97-9.

23. Geetha V, Doss A, Doss AP. Antimicrobial potential of Vitex trifolia Linn. Anc Sci Life 2004;23:30-2.

24. Ahmed MR, Anis M. Role of TDZ in the quick regeneration of multiple shoots from nodal explant of Vitex trifolia L.--an important medicinal plant. Appl Biochem Biotechnol 2012;168:957-66.

25. Deivam S, Anbu J, Ravichandran V, Senthilkumar KL. Antioxidant and anti-tumor activity of poly herbal extract on Ehrlich ascites carcinoma in mice. Int J Biol Pharm Res 2013;4:1103-7.

26. Goverdhan P, Diwakar B. Anti-nociceptive and anti-inflammatory effects of the leaf extract of Vitex trifolia Linn. In experimental animals. Ethnobot Leaf 2009; 13:65-72.

27. Kulkarni LA. Analgesic potential of Vitex trifolia Linn (Verbaneacae). Asian J Pharm Clin Res 2014;7:157-9.

28. Pfuzia A, Devi RB, Sharatchandra K, Debashree BN, Banylla SN, Sania KH, et al. Studies on the anti-inflammatory effect of the aqueous. Int J Pharm Bio Sci 2013;4:588-93.

29. Anandan R, Jayakar B, Karar B, Babuji S, Manavalan R, Kumar RS, et al. Effect of ethanol extract of flowers of Vitex trifolia Linn. On CCL4 induced hepatic injury in rats. Pak J Pharm Sci 2009;22:391-4.

30. Mohammed I, Garbi E, Osman EE, Kabbashi AS, Saleh MS, Mahmoud SA, et al. Cytotoxicity of Vitex trifolia leaf extracts on MCF-7 and vero cell lines. J Sci Innov Res 2015;4:89-93.

31. Wahyuono S, Alam G, Ikawati Z, Timmerman H, Maeyama K. Antiasthmatic compounds isolated from antiasthmatic "JAMU" ingredient legundi leaves (Vitex trifolia L.). Sci Pharm 2009;77:192-3.

32. Mamjunatha B, Vidya S. Comparative evaluation of wound healing potency of Vitex trifolia L. and Vitex altissima L. Phytother Res 2007;21:457-61.

33. Natheer SE, Sekar C, Amutharaj P, Rahman MS, Khan KF. Evaluation of antibacterial activity of Morinda citrifolia, Vitex trifolia and Chromolaena odorata. Afr J Pharm Pharmacol 2012;6:783-8.

34. Tiwari N, Thakur J, Saikia D, Gupta MM. Antitubercular diterpenoids from Vitex trifolia. Phytomedicine 2013;20:605-10.

35. Hossain MM, Paul N, Sohrab MH, Rahman E, Rashid MA. Antibacterial activity of Vitex trifolia. Fitoterapia 2001;72:695-7. 